\title{
Anything but a story foretold: Multiple politics of resistance to the agrarian extractivist project in Guatemala
}

\author{
Alberto Alonso-Fradejas
}

\begin{abstract}
Sugarcane and oil palm agribusinesses are in the vanguard of an emergent project of agrarian capitalism in Guatemala, which is defined here as a financialized and flexible type of agrarian extractivism. Meanwhile, Maya-Q'eqchi' residents of the northern lowlands believe that the changes in the labor regime, land relations and the agro-ecosystem that the expansion of these agribusinesses has brought threatens their subsistence in multiple and unfamiliar ways. Indeed, growing difficulties in dealing with (vital) grievances is leading many, even those who initially welcomed the corporate sugarcane and oil palm plantations, to transform their unrest into a practice of resistance. Elaborating on what is presented here as a multiple politics perspective, this article discusses the nature and character of such contemporary political dynamics of agrarian change. The forms, strategies, and practices of the two main and most antagonistic repertoires of contention are explored here: the one in "defense of territory" and the one in the promotion of the "agrarian extractivist project". The tensions across and within multiple corporate, state and social actors who are pushing for, resisting, complying with, or operating at the most violent margins of the agrarian extractivist project are also examined. By assessing continuities and ruptures between current and previous cycles of contention around the control of land, water and other natural resources, this article stresses the often-forgotten lesson about trajectories of agrarian change not being a story foretold, but the product of multiple and dynamic politics.
\end{abstract}

Keywords: Flex crops and commodities; land relations; labor regime; agrarian extractivism; multiple politics; frames and repertories of contention; Guatemala.

\section{Introduction}

Questions around the political dynamics of agrarian change regained momentum from the mid-2000s onwards, with the growing financialization of the economy (Fine 2012) and nature (Lander 2011) in general, and of agriculture (Isakson 2014) and land (Fairbairn 2014) in particular. Financialization shapes, and is shaped by, convergent economic, energy, environmental and food crises in a world historic juncture in which rapidly growing economies like the BRICS countries (Brazil, Russia, India, China and South Africa) and Middle-Income Countries (MICs) display a high demand for large amounts of raw materials and food. In short, favorable politico-economic conditions have been at play to (re)invigorate international accumulation projects based on the control of land, water and related natural resources (hereinafter land resources).

In the context of the many land resource-based accumulation projects spreading all over the country ${ }^{1}$, in 2008 , the government of Guatemala considered the spectacular figure of

\footnotetext{
${ }^{1}$ Such as mining, oil extraction, commercial tree plantations, carbon trading, hydro-power generation, cattle ranching, high-end tourism and narco-traffic money laundering. All these accumulation projects
} 
$1,101,604$ hectares, or thirty-seven per cent of the country's total farmland, to be suitable for sugarcane and oil palm cultivation (Alonso-Fradejas et al. 2011). These are not just any kind of tropical cash-crops but two important 'flex crops'. That is, they have 'multiple uses (food, feed, fuel, industrial material) that can be, or are thought to be, flexibly inter-changed' (Borras et al. 2014, 2). According to Borras et al., flex crops and commodities are highly valued these days because they

seem to deal with [the challenge of increasing price volatility in world markets] by reducing uncertainty in a single crop sector through diversification of the product portfolio, thereby enabling investors to better anticipate and more nimbly react to changing prices in either direction-e.g., to better exploit price spikes or to better withstand price shocks [in short] their multi-functionality helps to negate the purported trade-off between risk and yield on investments. $(2014,2,7)$.

Moreover, flex crops and commodities are better equipped to navigate regulatory constraints, and circumvent social opposition, thanks to their 'flex policy narratives' (Borras et al. 2014, 16), especially when displayed in a 'discursive flexibility' fashion. That is through 'the ability to strategically switch among multiple legitimating discourses which construe the necessary meanings and representations to achieve an objective' (Hunsberger and Alonso-Fradejas forthcoming). Indeed, legitimating narratives of the sugarcane and the oil palm agribusinesses spin around food and energy security, green energy generation and climate change mitigation, as well as economic development and even (rural) democratization.

A few years before the government's announcement, a group of agrarian, financial and industrial firms in the hands of a small-but-almighty post-colonial oligarchy (which occasionally allies with transnational investors and financiers) had already started taking control over large swaths of land for sugarcane and oil palm plantations. I stress the question of land control building on Borras et al.'s understanding of current land grabs as 'grabbing the power to control land and other associated resources such as water in order to derive benefit from such control of resources $[\ldots]$ control grabbing is inherently relational and political; it involves political power relations' (2012, 851). Indeed, as Holt-Giménez (2008) argues in the case of open pit gold mining in the Guatemalan western highlands, the expansion of corporate sugarcane and oil palm plantations is restructuring rural territories ${ }^{2}$ in a deep and comprehensive way. I suggest the means for such territorial restructuring has to do with the two complementing strategies of expansion of the oil palm and the sugarcane agribusinesses. One is what Harvey (2003) named the 'temporal deferment' of their investment. Current high revenues pay for costly and long-term investments including land and (flexible) oil palm and sugarcane mills. The other strategy is the making of governable spaces to fit their investment. That is, influencing not only formal regulatory frameworks and institutions, but especially,

shape, and are shaped by, increasing economic and logistical corridors, and mushrooming environmental enclosures (Alonso-Fradejas 2012).

${ }^{2}$ Understood as 'spatial assemblages of power relations and identity strategies [signifying] the 'bottomup' spatial contexts for identity and cultural difference (or place) more than the 'top-down' connections between state and territory' (Gregory et al. 2009: 745-746). 
ideas, discourses and practices of multiple state, corporate and social actors, across different scales ${ }^{3}$ and places ${ }^{4}$, to accommodate their accumulation interests. This, in turn, entails at least two distinct and major fixes. On the one hand, a labor regime fix to reshape the 'specific methods of mobilizing labor and organizing it in [capitalist agriculture] production, and their particular social, economic and political conditions' (Bernstein 1988 31-32 in White et al. 2012, 622). This article discusses the ways in which flex crop agribusinesses are reducing local wage work opportunities, while enforcing a community-detached, flexible and hyper-commodified labor regime which does not allow workers to make ends meet. There is, on the other hand, a land "good governance" fix performing 'as a persuasive ethical power that allows for selfregulation, making it possible for governments to intervene less intrusively and more efficiently' (O'Laughlin 2008:946). This implies the production of a durable consensus around a particular rationality of governing land resources, which not only meets the agribusinesses' interests, but is also perceived as desirable by concerned state and social actors. This land good governance fix is rooted in the freehold land tenure imperative, which has been spread since the early 1990s through IFAD- and World Bank-promoted Market-Led Agrarian Reform. As we shall see, the workings towards the labor regime and land good governance fixes do not just involve the use of physical force and violence, but also, and increasingly, that of different means of enticement and of economic and legal coercion which are 'involved in the governance of conduct and, a fortiori, in the production of hegemony' (Jessop 2010, 342).

Current sugarcane and oil palm agribusiness accumulation and governmental projects are the main vectors and expressions of what I consider to be an emergent but major transformation in agrarian capitalism in Guatemala, and arguably in other similar national contexts in Latin America and elsewhere. Clearly, capitalist social relations of production were already dominant long before the beginning of the $21^{\text {st }}$ Century, though unevenly internalized across traditional landed upper classes, peasant classes and rural laborers (see the seminal works of Martínez Peláez 1976, Figueroa Ibarra 1980, Handy 1984, and Hurtado 2008 among others). Nonetheless, I suggest that from the mid-2000s onwards a distinctive project of agrarian capitalism is emerging in Guatemala, which could be aptly described as a financialized and flexible type of agrarian extractivism.

In short, there are three main and convergent dynamics at play in the Guatemalan countryside informing this work-in-progress analysis ${ }^{5}$. Firstly, agricultural production in

\footnotetext{
${ }^{3}$ Comprising 'the nested (and sometimes not so nested) hierarchy of bounded spaces of differing size' (Jessop 2007: 104,105).

${ }^{4}$ Broadly understood as a 'unit of space that has discrete boundaries, shared internal characteristics, and that changes over time and interacts with other similar units' (Gregory et al. 2009: 539)

5 This preliminary argument for, and understanding of, an emergent agrarian extractivist project is inspired by the reflection on my empirical research in the Guatemalan countryside since 2003 in the light of two main analytical threads. On one side, the classic agrarian question posed by Marx (1974[1867]) and further developed by Engels (1970[1894]), Kautsky (1988[1899]) and Lenin (1964[1899]). Particularly, the later discussion by Byres $(1991,1996)$ and Bernstein $(2004,2006)$ about the need revisit the classic agrarian question(s) in the socially diverse contexts of the South today. On the other side, the vivid debate on the politics of 'neo-extractivism', around mining and hydrocarbons extraction projects in Latin American states with progressive governments (Gudynas 2009, Veltmeyer and Petras 2014, Acosta 2013, Bebbington 2007, Leff 2006, and Martínez-Alier 2002 among others). Especially, the need to
} 
commercial sugarcane and oil palm plantations is being reshaped by the increasing use of new farming techniques, such as precision agriculture, and especially of highly versatile biotechnologies. Contrary to their promised outcomes, these technologies are increasing the already heavy dependency of modern agricultural production on petrochemicals and other costly inputs. In this search for ever-growing yields to maximize profit: i) the knowledge rift between traditional ways of farming and those relying on biotechnologies and information technologies is severed, excluding those producers unable to meet the required capital intensity, or reducing them to little more than lessors of landed-property and occasional labor (i.e., most contract farmers) (see Goodman et al. 1987, Netting 1993, and Altieri and Toledo 2011, among others); and ii) the metabolic rift between agricultural production and the ecosystem is pushed beyond the limit allowing for the biophysical reproduction of soil nutrients, underground fresh water sources and agro-biodiversity (see Mingorría et al. 2014, Moore 2011, IAASTD 2009, Akram-Lodhi and Kay 2009, and Foster 2000, among others).

Secondly, as mentioned earlier, the labor regime brought about by oil palm and sugarcane agribusinesses limits wage work opportunities without accommodating a living wage to most plantation workers (Hurtado and Sánchez 2011, Alonso-Fradejas et al. 2011). While labor and labor arrangements are flexibly organized to maximize surplus extraction, the working conditions are damaging workers' physical and mental health in severe and even deadly ways (Hurtado and Sánchez 2011, Alonso-Fradejas et al. 2011). Indeed, somehow differently from the classic formulation of agricultural commodity production "freeing" labor from landed property towards a nascent industrialization, the flex-crops labor regime is freeing agricultural labor, but this is not being absorbed in any other productive realm of the economy. This "free" labor turns into a sort of expendable 'relative surplus population' (Marx 1974[1867]) with no, or little, prospects for either (self-)employment or state support (Li 2011).

And, thirdly, as advanced by Bernstein in his review of the classic agrarian question in times of globalization, 'the range of non-agrarian, non-indigenous sources of agrarian capital is likely to expand and diversify, and their significance to increase, over the history of capitalism' $(2006,10)$. In today's oil palm and sugarcane plantations, the surplus value and the land rent generated are no longer appropriated by local landed upper classes, nor subsidizing an industrialization project. They are instead, increasingly appropriated by financialized capitals exerting an increasing control throughout the flex commodity value chain(s), from production to transformation, fractionation for multiple uses, industrialization, shipping and retailing (see Fairbairn 2014, Isakson 2013, Solano 2009, and Goodman et al. 1987, among others).

I suggest, then, that engaging with the politics of the making of governable spaces to accommodate the agrarian extractivist project $^{6}$ is a meaningful means to assess the political dynamics of contemporary agrarian change in Guatemala. Elaborating on

contextualize this debate: 1) in contemporary accumulation projects in the realms of biomass in general, and agriculture in particular, and; 2) in non-progressive government Latin American states, like Guatemala.

${ }^{6}$ So far, I have approached agrarian extractivism as an accumulation and governmental project, which might or might not coalesce in a distinctive regime of accumulation within capitalism. 
research since $2006^{7}$ on the politics of sugarcane, and especially oil palm agribusinesses' expansion in the Guatemalan northern lowlands (see figure 1 below), I will describe the broad contours of major economic, political and ideological distribution conflicts fuelling what could be well considered a new 'cycle of contention ${ }^{8}$ in the Guatemalan countryside. In so doing, I will elaborate on what I call a multiple politics perspective. This methodological approach is considered to be helpful in circumventing aprioristic and/or reductionist assessments of usually complex, dynamic and erratic politics of contention around land and natural resources control, in socially diverse, geographically and historically situated agroecological settings. Analytical attention is given to multiple state, corporate and social actors and to their fluid ideological and political positioning in time. This allows for an assessment of the nature and character of multiple and dynamic relations among such actors or, in other words, of the politics within the politics of contention.

Nonetheless, the main interest in this collection is to focus on what Borras and Franco framed as the differentiated "political reactions "from below" - e.g. among groups of poor, vulnerable and marginalised people and peoples who are affected by large-scale land deals' $(2013,1724)$. I will, therefore, attempt to put forward an initial discussion on why, how and whose dissent turns into a practice of resistance to changing labor and land control relations in the Guatemalan countryside. In doing so, I will discuss some of the politics between historically antagonistic forms of organizing agrarian production and of governing land resources (i.e. agrarian extractivism vs. indigenous-peasant farming), the politics across multiple actors resisting agrarian extractivism (e.g. grassroots groups and organizations vs. national militant peasant movements) and the politics within particular groups of actors in resistance (e.g. the indigenous "peasantry").

Beyond a series of conclusions regarding ruptures and continuities between current and previous cycles of contention, my main point here is one over which I claim no novelty, but believe to be worth stressing nonetheless: that trajectories of agrarian change are not a story foretold, but the product of multiple and dynamic politics.

\section{Q'eqchi' lowlanders' grievances about expanding oil palm and sugarcane agribusinesses}

The Guatemalan northern lowlands encompass almost half of the national territory and are mainly inhabited by the Maya-Q'eqchi' peoples ${ }^{9}$ (hereinafter Q'eqchi'). It is in this agrarian frontier that the (1.6 million-hectare) Mayan Biosphere Reserve coexists with tens of thousands of indigenous cultivators supplying Guatemalan and Central

\footnotetext{
${ }^{7}$ Research methods include geographic information system analysis, interviews, participatory observation and a gender differentiated household survey carried out in October 2010. The survey's sample was stratified by village (significance level 5 per cent) and included 294 randomly selected households (586 surveys) in twenty villages of six municipalities within the northern lowlands (see figure 1).

${ }^{8}$ Understood by Tarrow as 'less momentous than revolutions, more connected than contingent chains of events' (2012: 215)

9 The Q'eqchi', with an estimated population of more than two million people is probably (since last official population census dates back to 2002) the largest of the 22 Mayan peoples in Guatemala.
} 
American food markets, traditional coffee estates and cattle ranches, and more recently, sugarcane and oil palm agribusinesses. As mentioned, this article builds on research since 2006 in various villages from six municipalities within three distinct sub-regions of the northern lowlands depicted in figure 1 below.

Figure 1: Research sub-regions, departments and municipalities in the Guatemalan northern lowlands region

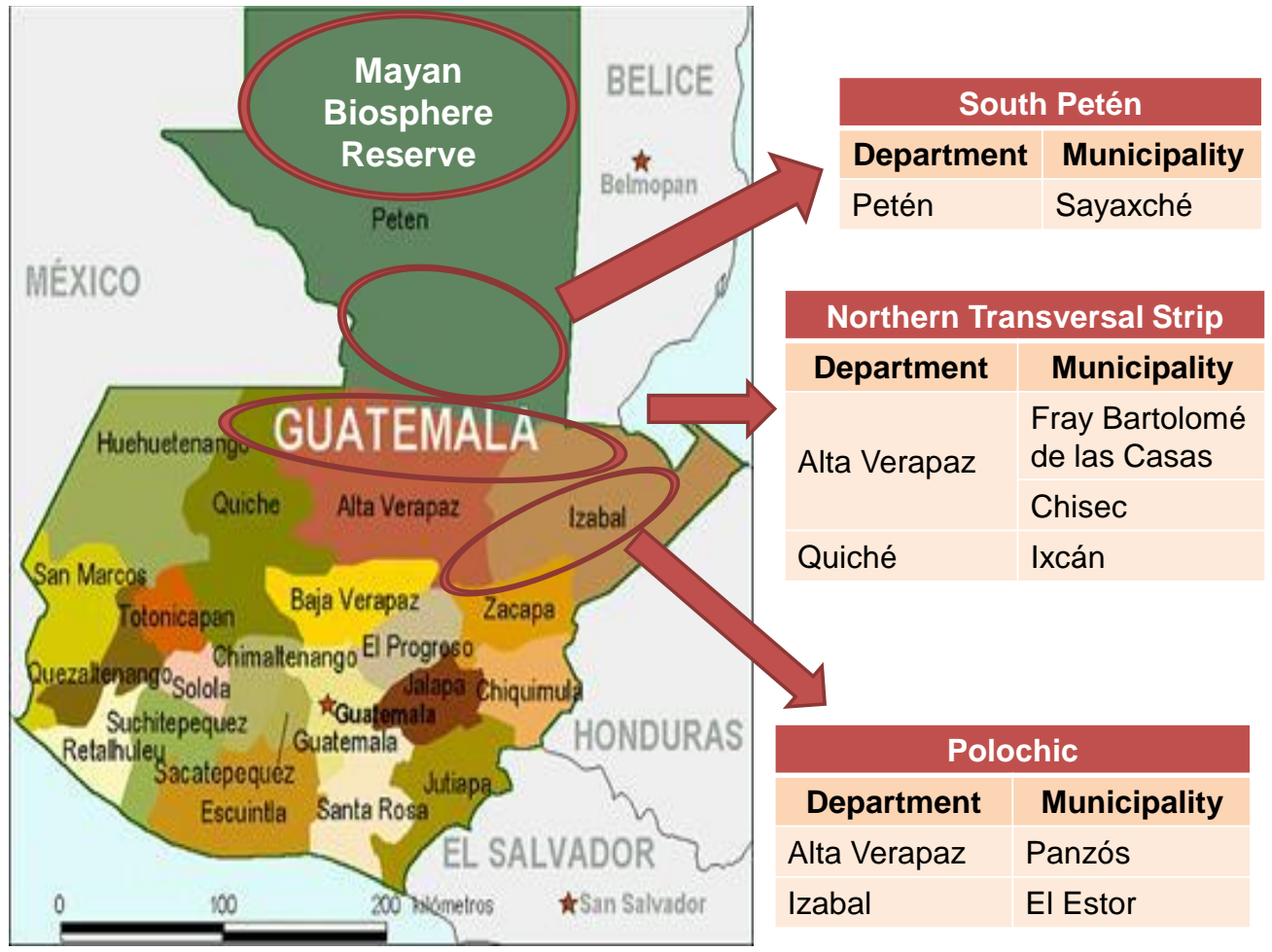

Source: Author's elaboration based on Government of Guatemala 2009. Scale: 1:3,000,000.

The three sub-regions share a tropical climate, and an altitude of below 500 meters above sea level but show significant differences in their historical constitution. As Edelman and León (2012) remind us, putting changing social relations around land and agricultural production into a historical perspective is a sine qua non condition to assessing their character, and discussing their possible trajectories. At the risk of oversimplification, since a fully-fledged historization of the three sub-regions goes beyond the scope of this article, I suggest two distinct processes of territorialization that characterize the social construction of the Polochic ${ }^{10}$ on the one hand, and South Petén and the Northern Transversal Strip ${ }^{11}$ on the other. The Polochic river valley fertile lands were first granted to German settlers, "white" Guatemalan oligarchs and government cronies by the national state in the 1870 s, and they set about establishing large coffee estates. Q'eqchi' families living in the area were incorporated into the estates under the colonato $^{12}$ labor regime. As an in-between tenancy and bonded-labor arrangement, this

\footnotetext{
${ }^{10}$ See Wagner (2001), Grandin (2004) and Hurtado (2008).

${ }^{11}$ See Schwartz (1990), McCreery (1994), Castellanos (1996 [1985]) and Grandia (2012) among other relevant background sources.

${ }^{12}$ For a fresh review of the colonato regime in Guatemala see Hurtado (2008).
} 
relation of production has many variants that evolved through time and place in Guatemala and elsewhere in Latin America. It generally combined wage labor with inkind or labor payments to the landlord (patron) in exchange of the colono family's right to live and farm (only) self-sufficient crops in the patron's hacienda. Families expelled from, or fleeing the haciendas, settled in the hilly lands surrounding the valley during the $20^{\text {th }}$ Century. Other remained as colonos in the haciendas up until very recently. Further north, the agrarian colonization of Petén and the Northern Transversal Strip rainforests was sponsored by military regimes in compliance with the counterrevolutionary land policies following the 1961 Alliance for Progress Initiative. Since then, thousands of families (especially Q'eqchi') fleeing the colonato labor regime (e.g. in the Polochic) and/or the violence associated with the genocidal war ${ }^{13}$, arrived in these two sub-regions in search of farmland. Alongside this majority of landless and indigenous populations, "white" traditional large-scale landlords, small and mediumsized "ladino"14 cattle ranchers, and government and military officials also arrived in South Petén and the Northern Transversal Strip during the second half of the twentieth century.

It is within these milieus, where traditional haciendas and ranches coexist with capitalist agriculture and peasant farming, that the sugarcane and oil palm agribusinesses are harnessing control over land resources. That is, according to Ribot and Peluso, they are controlling 'the ability to mediate others' access' $(2003,158)$. Control over access is just one amongst the three dynamics 'constitutive of relations among actors in relation to resource appropriation, management or use' (Ribot and Peluso 2003, 158); these are gaining, maintaining and controlling access to resources (Ribot and Peluso 2003). There were active land and labor markets in the northern lowlands long before the mid2000s. But it is since then, and in the context of renewed interests in land resource control for accumulation purposes as mentioned above, that the Market-Led Agrarian Reform (MLAR) and land titling programmes implemented by the state land fund (FONTIERRAS) rendered local land resources commodities of interest to capitalized "outsiders". Crucially, this set the conditions for major changes in the social relations around land and around capitalist agricultural production, which ultimately became major sources of unrest among Q'eqchi' lowlanders. These sources of unrest are intimately linked to a series of historically constituted and interrelated grievances of an agrarian, socio-ecological and ideologico-political nature, as well as to grievances related to the "terms of incorporation' 15 into the emergent agrarian extractivist project.

Agrarian grievances are related to directions of change in land control relations. Broadly speaking, there are two categories of landless people in the northern lowlands. The first, and larger one, is that of second and third generation descendants of the 1960s' settlers.

\footnotetext{
${ }^{13}$ During the 36 years of war, and especially under the early 1980's military-led scorched earth policy, there were also 160 massacres in these sub-regions. The 1996 Peace Agreements lead to the official end of a conflict which left 200,000 people killed or disappeared. Over 80 per cent of the victims were civilian, rural, Maya indigenous people (Comisión para el Esclarecimiento Histórico 1999).

${ }^{14}$ This is akin to the mestizo racialized identity elsewhere in Latin America.

15 Ranging from advantageous to adverse terms and conditions of people's incorporation into an accumulation project (Du Toit 2004: 1003)
} 
The second group comprises those who became landless in the context of expanding sugarcane and oil palm plantations. Eleven per cent of the families from the studied areas in the northern lowlands lost their land tenure rights between 2000 and 2010, mostly in order to give way to oil palm and sugarcane plantations (Alonso-Fradejas 2012, 518). Indeed, the land use change analysis between 2005 and 2010, depicted in figure 2 below, shows that twenty-three per cent of the lands used for oil palm in 2010 were previously used by small-scale cultivators to grow staples.

Figure 2: Land uses in year 2005 of the land under oil palm cultivation in 2010. Guatemalan northern lowlands

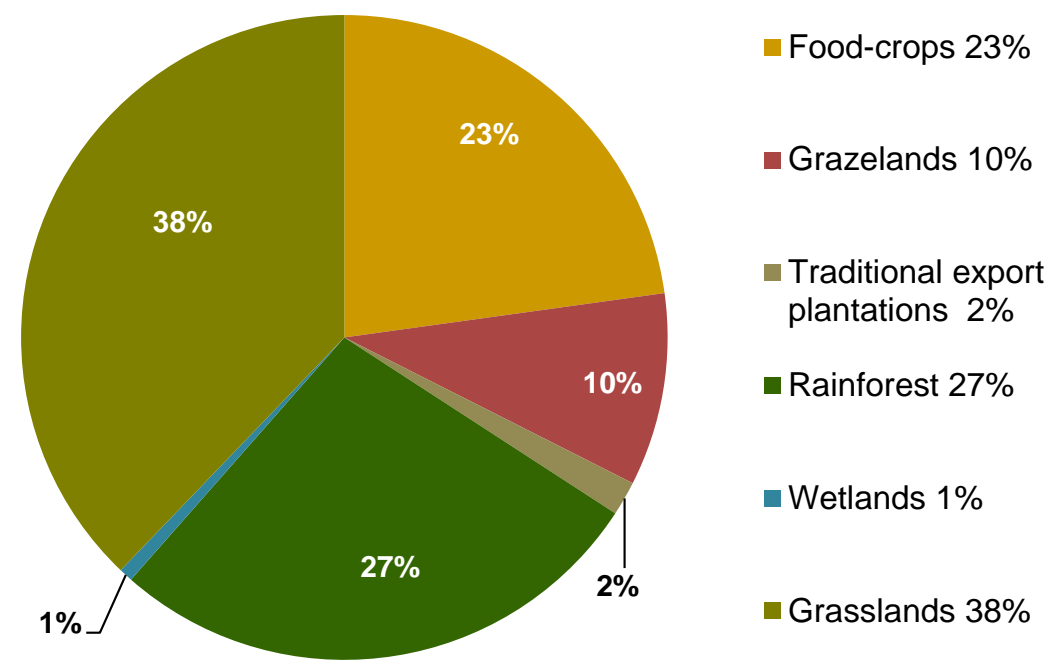

Source: Alonso-Fradejas et al. (2011)

The land currently under the control of oil palm and sugarcane agribusinesses was privately titled by the state, with the result that corporate acquisitions could be considered as perfectly "legal". As the manager of a leading oil palm company argues, 'land acquisitions, at least by us, have always been legal. If the transaction is legal I do not see any problem. We have the right to buy [...] When buying land, we must be sure there is not a single problem with the title' (quoted in Hernández 2012, stress added). However, almost half of the surveyed male heads-of-household who lost their land, and were not working for an oil palm or a sugarcane company when surveyed, said they were compelled to sell their land. A third of them said they sold it because it was useless for farming, and the rest because they were highly indebted. Meanwhile, the meager payment most Q'eqchi' peasant families received for their land did not allow them to develop alternative non-farming livelihoods, nor to regain access to farmland (Alonso-Fradejas 2012, 519).

Socio-ecological grievances are associated with changing land- and water-scapes. Figure 2 above shows that twenty-seven per cent of the lands used for oil palm in 2010 were rainforests in 2005, whilst one per cent were wetlands, and thirty-eight per cent grasslands. Rivers are usually diverted to irrigate plantations and, together with other fresh water sources, have become contaminated with sugarcane mill vinasses, oil palm 
mill effluents and different petro-chemicals (Alonso-Fradejas et al. 2011). The expansion of flex crops is redrawing the land and water-scapes of fragile socioecological systems and having a detrimental impact on these.

There are also far-reaching ideologico-political grievances. As expressed by a middleaged Q'eqchi’ peasant man from the Sayaxché municipality,

we, the Q'eqchi', are facing a major problem. Our thinking is being dominated as well as our beliefs. This is the result of the way the powerful and rich people think. Of those who want to dispossess us from our lands once again. (Group meeting, March 2010)

Indeed, many Q'eqchi' lowlanders feel outraged at the fact that they are losing the land and autonomy they fought so hard for as swidden cultivators who settled as far as possible from estate patrons and state officials.

Finally, the expansion of oil palm and sugarcane over lands previously dedicated to peasant and small-scale capitalist farming is eroding local wage labor opportunities because it is much less labor-intensive. As depicted in figure 3, oil palm and sugarcane require 52 and 36 working days per hectare/year respectively, while, for instance, the two annual maize harvests require 112 and chili cultivation 184 working days.

Figure 3: Working Days per Ha/year in peasant farming, petty commodity production, sugarcane and oil palm (2009)

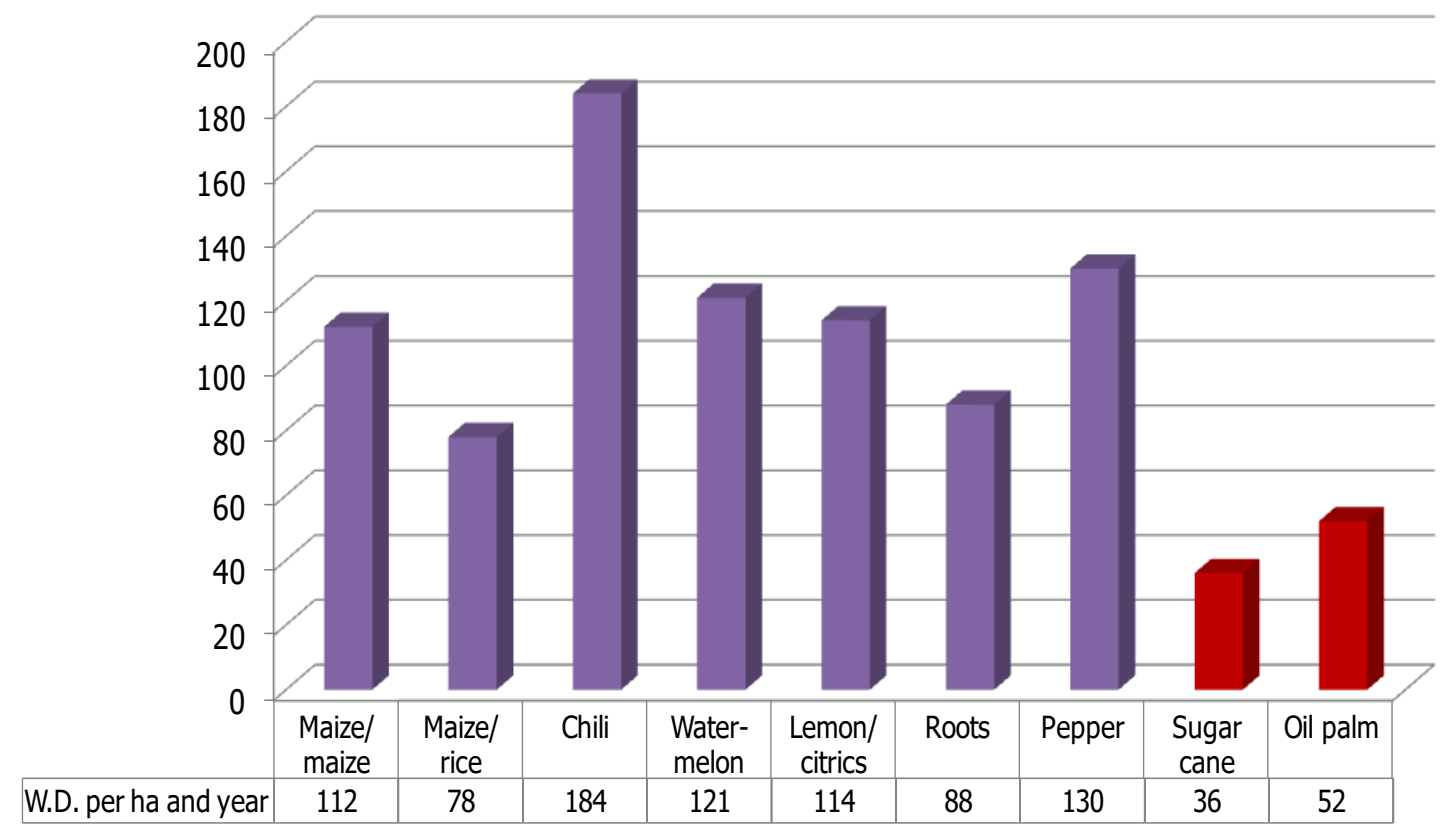

Source: Dürr (2011). "Maize/maize" refers to the two annual harvests of maize on that hectare of land.

Besides, many of those incorporated into the agrarian extractivist project as plantation workers or small-scale outgrowers, feel they were adversely so. Firstly, piece-meal wages are common in plantation work, and do not cover even the basic food basket cost (Alonso-Fradejas et al. 2011). Working arrangements and conditions are flexible in time and space and outsourced via subcontracted crews, thus lack labor liability (Alonso- 
Fradejas et al. 2011). Furthermore, workers and people living nearby the plantations claim they are suffering from a series of accidents and maladies related to the forms of oil palm and sugarcane production. Machete cuts, sunstroke, dehydration, snake bites, gastrointestinal problems from polluted drinking-water, back, shoulders and wrist injuries due to lifting heavy oil palm fresh fruit bunches, and breathing problems due to the smoke from pre-harvest sugarcane field burning, amongst others, have been reported (Alonso-Fradejas et al. 2011). Most distinctively, a rare kidney disease is killing thousands of sugarcane cutters all over Central America (Sanders and Riordan Seville 2012). In addition, fetal malformations are related to aerial agrochemical spraying (interview with the doctor in charge of Teleman (Panzós) public health posts, June 2009) and increasing rates of venereal diseases to mushrooming brothels (interviews with representatives from $A Q T$, Q'eqchi' women organization, in Chisec, February 2010, and from Mamá Maquín, in Fray, November 2013). Secondly, lack of technical assistance and access to enough credit, together with variable pricing and high quality and uniformity standards for the oil palm fresh fruit bunches delivered by small-scale outgrowers, are forcing many out of contract-farming, and even into landlessness. Within the emergent labor regime, Bernstein's 'agrarian question of labor' becomes a central one: "what if the forms of capitalism, including industrialization [...] in the South today are incapable of generating sufficient, and sufficiently secure, employment to provide 'a living wage' to the great majority?' $(2006,13)$.

Overall, these grievances are related to concrete issues that make it harder for many to make ends meet. Different groups of Q'eqchi' lowlanders feel their 'subsistence minimum' (Scott 1976) is being violated. This feeling is enhanced by narrowing (or breaking) moral economic arrangements of inter-class reciprocity (Thompson 1971, Scott 1976). The moral economy relations which allowed for the continuous (re)negotiation of survival standards between (non-indigenous) traditional landed upper classes, capitalist farmers, and what are becoming fully-fledged Q'eqchi' rural 'classes of labor' ${ }^{16}$, are fading away. As argued by an elder Q'eqchi' man and former landless movement organizer:

Sometimes I wonder if we have advanced at all. As colonos in the estate the patron forced us to work for almost nothing. Still, we had a patch of land to grow our maize. If anything went wrong with the harvest, he would never let us starve. He looked after us because he needed us. Now we are free labor, they say. Free to starve, I say. The rich people do not need us and so do not care about us anymore (interview in Panzós municipality, November 2007).

The previous statement is very telling of historically constituted subsistence levels among Q'eqchi' lowlanders across different agricultural labor regimes. Elders often argue that even though patron-client relations under the colonato labor regime were exploitative and humiliating, they still allowed for the continuous renegotiation of the

\footnotetext{
16 According to Bernstein, these include all those who 'have to pursue their reproduction through insecure, oppressive and increasingly 'informalised' wage employment and/or a range of likewise precarious small-scale and insecure 'informal sector' ('survival') activity, including farming; in effect, various and complex combinations of employment and self-employment' (2010: 73).
} 
minimum requirements for the reproduction of the family. Even during the outbreak of neoliberalism in Guatemala (arguably from the mid-80s on) and throughout the phase of agrarian capitalism under neoliberal globalization, wage and working conditions of seasonal and/or occasional laborers were still based on similar (if not celebrated at least tolerated) moral economy arrangements. Things have changed from the mid-2000s on under the impersonal, hyper-commodified and precarious flexible labor regime enforced by oil palm and sugarcane agribusinesses. Wages, labor arrangements and conditions are standardized by absentee owners and inaccessible managers, so it has become far more difficult to negotiate subsistence minimums, compared with the past. In addition, multiple attributes in terms of class, gender, age and their manifold intersections, lead to multiple interpretations of what subsistence means, and where its minimum threshold lies. For instance, Q'eqchi' food cultivators (landed or not, occasional laborers or otherwise) show not only higher expectations, but also higher satisfaction levels, regarding their reproduction needs in comparison to non-farming Q'eqchi' laborers (Alonso-Fradejas et al. 2011). Poorer Q'eqchi' women tend to include access to drinking water, firewood, housing materials and medicinal plants, as minimum requirements for subsistence more often than less-poor women and men in general (Alonso-Fradejas et al. 2011). Q'eqchi' elders consider access to, and respect for, sacred places a must, while youngsters across genders and classes generally hold urban living standards in higher regard, and claim that access to information technologies is important for them. Despite the fact that grievances are experienced in different ways, growing difficulties in dealing with them are leading many to transform their unrest into a practice of resistance.

\section{Q'eqchi' lowlanders' resistance to expansion of sugarcane and oil palm agribusinesses}

Resistance can be approached as a complex and non-linear process of defiance, which often combines a messy group of practices of a material and ideational nature. Its capacity to sustain itself is contingent on multiple interventions and tensions between, across and within contenders in different scales and places. In engaging with situated practices of resistance of the Q'eqchi' lowlanders, I will discuss the way they frame their unrest within and across communities and social groups, through 'shared understandings and identities that justify, dignify and animate collective action' (Tarrow 1998, 21). I will go on to describe the different forms and particular strategies of resistance to agribusiness expansion informing the $\mathrm{Q}^{\prime}$ eqchi' repertoire of contention. That is, 'the ways people act together in pursuit of shared interests' (Tilly 1995, in Tarrow 1998, 30)

\section{Resistance framed as defense of territory}

A synthetic review of the recent history of master frames of contention in rural Guatemala is useful to understand the way Q'eqchi' lowlanders frame their struggles today. During the war (1962-1996), revolutionary uprising relied upon urban and (mainly) rural poor working classes-in-and-for-themselves. Indigenous peoples' 
demands were contingent upon the triumph of the revolution. National peasant organizations related in different but militant ways to guerilla groups and/or to Catholic Liberation Theologians, and framed their contention for a land-to-the-tiller land reform as part of the broader revolutionary struggle. Some of these organizations disappeared, but others remain active and will be addressed here as "militant" organizations, often with (inter)national scope.

Neoliberalism was forged and enforced in Guatemala a decade before the Peace Agreements were fully signed in 1996. By then, outcomes of the Washington Consensus' deregulation, liberalization and privatization imperatives were already a major cause of grievances across (rural) classes of labor. The 1992 National Peasant Congress echoed the problems related to unfavorable terms of (agricultural) trade and the dumping of cheap, subsidized corn from the USA. Nonetheless, after the bloodiest scorched-earth massacres were inflicted by the military during the eighties ${ }^{17}$, and popular expectations for the revolution's success languished, militant peasant organizations and others framed their contention as a struggle for life (lucha por la vida) prioritizing the state's respect for politico-civil rights. It was only after 1996 and in the context of deepening neoliberal globalization, that militant peasant organizations embraced food sovereignty ${ }^{18}$ as their master frame of contention against the TNCcaptured world agri-food system characteristic of the dominant food regime (Friedmann and McMichael 1989).

On top of the exclusion of the (indigenous) peasantry from food, labor and credit markets, and the drastic reduction of public support for their forms of farming during agrarian capitalism under the orthodox neoliberal globalization period, from the mid2000s onwards they became also excluded from controlling the most productive land resources, as previously discussed. It is in this context that resistance to the emergent project of agrarian capitalism, which I am branding as agrarian extractivism, came to be framed as defense of territory. In essence, this is not a novel concept. The right of native peoples to territory was already enshrined in the ILO Convention 169 in 1989. It was further developed in the UN Declaration on the Rights of Indigenous Peoples in 2007. Notwithstanding its formal regulatory history, I suggest that it is only within the current cycle of contention in the Guatemalan countryside that a discourse on "territory" has been: i) appropriated by larger (other than the leaders of the national indigenous movement) and wider (other than Mayan indigenous peoples) grassroots constituencies. Indeed, a historically distinctive feature of defense of territory today has to do with its development and enactment from below. There are, of course, charismatic leaders and ideologues elaborating on the concept. But it is from the grassroots that such actors in particular, and (national) militant peasant organizations more generally, adopt this

\footnotetext{
${ }^{17}$ Rios Montt, one of the most influential Generals at the time, was convicted by a Guatemalan court for genocide and crimes against humanity on May 10, 2013. Ten days later, the Constitutional Court reversed the verdict. The case was still open during the writing of this article.

${ }^{18}$ See The Declaration of Nyéléni for a definition: http://www.nyeleni.org/IMG/pdf/DeclNyeleni-en.pdf For a critical discussion on the food sovereignty vision see the three special issues in the Journal of Peasant Studies (41:6 2014), Globalizations (forthcoming 2015) and Third World Quarterly (forthcoming 2015).
} 
master frame of contention; and ii) politicized via a strategically essentialized discourse on (collective) rights. As argued by an influential Q'eqchi' ideologue (lawyer and Member of Congress) the ultimate goal of this frame of contention is to "move from practices of cultural resistance to the full exercise of collective rights in the territory' ${ }^{19}$.

As we will see below, and contrary to what the etymology of "defense" may suggest, defense of territory entails defensive and oppositional practices as well as propositional ones, regarding strengthening "peoples' sovereignty" over their life territories. Among other things, it could be argued that defense of territory aims to bring together two distinct, but intimately related, visions: One is a vision for a self-determined government of social relations of access, control, and use of land resources. Accordingly, 'a government agency, an oil palm company or a conservation NGO needs to deal not with individuals but with a collective rights subject that is the indigenous community, via its particular institutions of government ${ }^{20}$. The other is a territorialized vision of food sovereignty, to inform social relations around food production and distribution. Indeed, defense of territory for Q'eqchi' lowlanders is rooted in their selfrepresentation as R'al Ch'och (Sons and Daughters of the Earth). This shared ethnic identity intertwines with one of a traditional sort of (self-sufficient) peasant class for itself (even if often no longer "in itself") to dignify, encourage and justify Q'eqchi' collective action in defense of territory.

\section{Q'eqchi' lowlanders' repertoire of contention in defense of territory}

Tilly understood the repertoire of contention as 'the whole set of means that a group has for making claims of different kinds on different individuals or groups' (1986, 4, in Tarrow 2012, 222). Q'eqchi' lowlanders' repertoire of contention in defense of territory is informed by corporate agents, government officials, national militant organizations and other allies of the indigenous-peasant movement. For Tarrow, social movements are 'those sequences of contentious politics that are based on underlying social networks and resonant collective action frames, and which develop the capacity to maintain sustained challenges against powerful opponents' $(1998,2)$. But as Tilly remarks, 'social movements are a particular, historically discrete form of organizing contention and not the be-all and end-all of contentious politics' (2004b, in Tarrow 2012, 222). Evidence from the northern lowlands suggests struggles in defense of territory are organized in both these ways, namely via more structured social movements and other relatively less structured forms. Hence, I will discuss now a constellation of resistance practices involving both overt-but-occasional structured forms, and surreptitious-but-ubiquitous everyday forms, as summarized in Figure 4 below.

\footnotetext{
${ }^{19}$ In APROBASANK's workshop in Guatemala City, June 262013

${ }^{20}$ In APROBASANK's workshop in Guatemala City, June 262013
} 
Figure 4: Forms, strategies and practices of the repertoire of contention in defense of territory

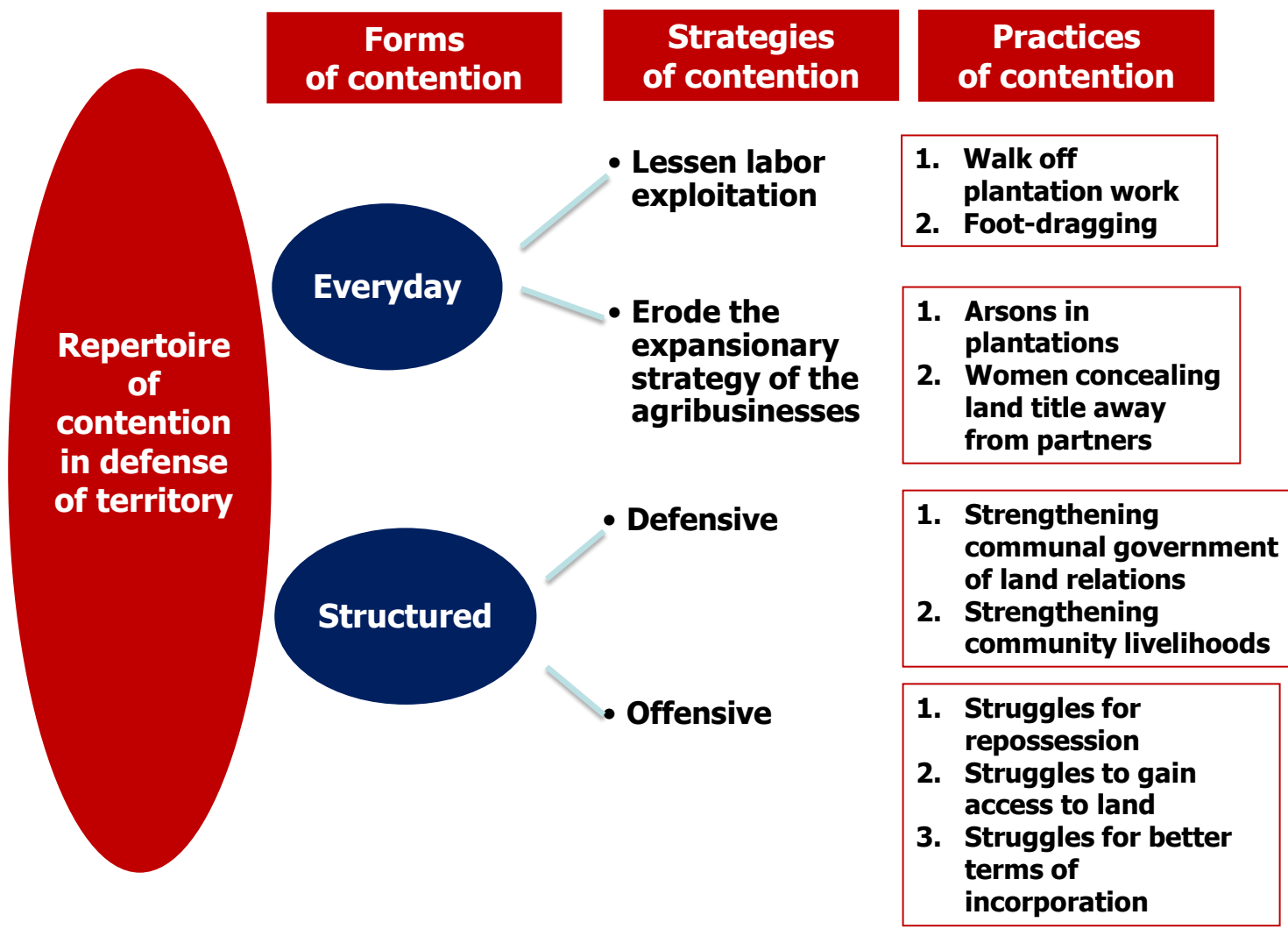

Source: Author's elaboration

Scott defined everyday forms of resistance as 'the nearly permanent, continuous, daily strategies of subordinate rural classes under difficult conditions' (1986, 22). In addition to frequent gossiping and grieving in trust networks, there are at least four other recurrent practices of everyday resistance to flex crop agribusinesses by Q'eqchi' lowlanders. I have clustered them in two couples here. The first couple is particular to landless or occasional wage laborers. It is aimed at reducing exploitation in plantation work. One resistance practice here is walking off plantation work without prior notice or subsequent justification. Sometimes this becomes a group response either to unfulfilled promises by the agribusinesses (e.g. to support the community school) or to offences by foremen. There are, in fact, several cases where a community agreement stipulates not to work for a sugarcane/oil palm agribusiness. The other resistance practice is footdragging and reporting more work than actually performed. In the municipalities of Ixcán and Chisec, though, foot-dragging turned into defiant sabotage during 2011 and 2012. Full sacks of agro-chemical were buried instead of applied to oil palms. Drain canals were dug, but only next to the roads through which supervisors drove by, and not alongside the plantation. This almost led the main oil palm company in the area to face bankruptcy (interview with a small-scale oil palm outgrower, Chisec, July 2013). However, the company was refloated with new funding, and, in retaliation, local laborers are no longer hired. 
The other couple of everyday practices of resistance is particular to the peasantry, and part of a strategy aimed at eroding the expansionary strategy of the agribusinesses. One resistance practice has to do with a wave of arsons. In 2007, dozens of oil palms caught fire in South Petén when cultivators burnt their fields in preparation for farming. When questioned by private security or the police, village members would associate such incidents with "unintended negligence". Nonetheless, oil palm companies sued the owners of the plots from which the fire spread out, and asked for US\$1,875 per burned oil palm ${ }^{21}$. This was considered to be terribly unfair by the peasants, who, in many cases, found no other option than to sell or give their land as in-kind payment to the company. Similar events took place in 2007 and 2008 in the Polochic Valley. The differences were that the maize cultivators were simply leasing the land; that both sugarcane and oil palm plantations were partially burnt; and payment to the agribusinesses was not in-kind, but as free labor. The other practice of resistance is carried out by Q'eqchi' peasant women, and it involves them concealing land titles so their partners find it more difficult to sell the family plot. Indeed, 86 per cent of female heads-of-household within those households who sold their land between 2000 and 2010, was openly opposed to the sale (Alonso-Fradejas 2012, 519).

Despite the fact that everyday forms of resistance by the rural poor are ubiquitous, Scott also argued how 'at times of crisis or momentous political change may be complemented by other forms of struggle which are more opportune. [Everyday forms] are the stubborn bedrock upon which other forms of resistance may grow' (1986, 22, stress added). Everyday forms of resistance in the northern lowlands are increasingly complemented by, or scaled-up towards, more structured forms of defiance. As of July 2012, the Guatemalan Secretariat of Agrarian Affairs reported ' 1,214 cases of unresolved conflicts in the countryside (involving) 1,000,055 peasants claiming rights over 338,935 hectares of land' (Prensa Libre September 4, 2012). Figure 5 below shows how 76.4 per cent of the different land conflicts reported by the Secretariat (not limited to those related to oil palm and sugarcane expansion) were concentrated in the northern lowlands region.

${ }^{21}$ The official monthly minimum wage in Guatemala was of US\$ 190 in 2007 (Alonso-Fradejas et al. 2011: 45). 
Figure 5: Geographical location of the 1,214 agrarian and environmental conflicts registered by the Government of Guatemala in 2012

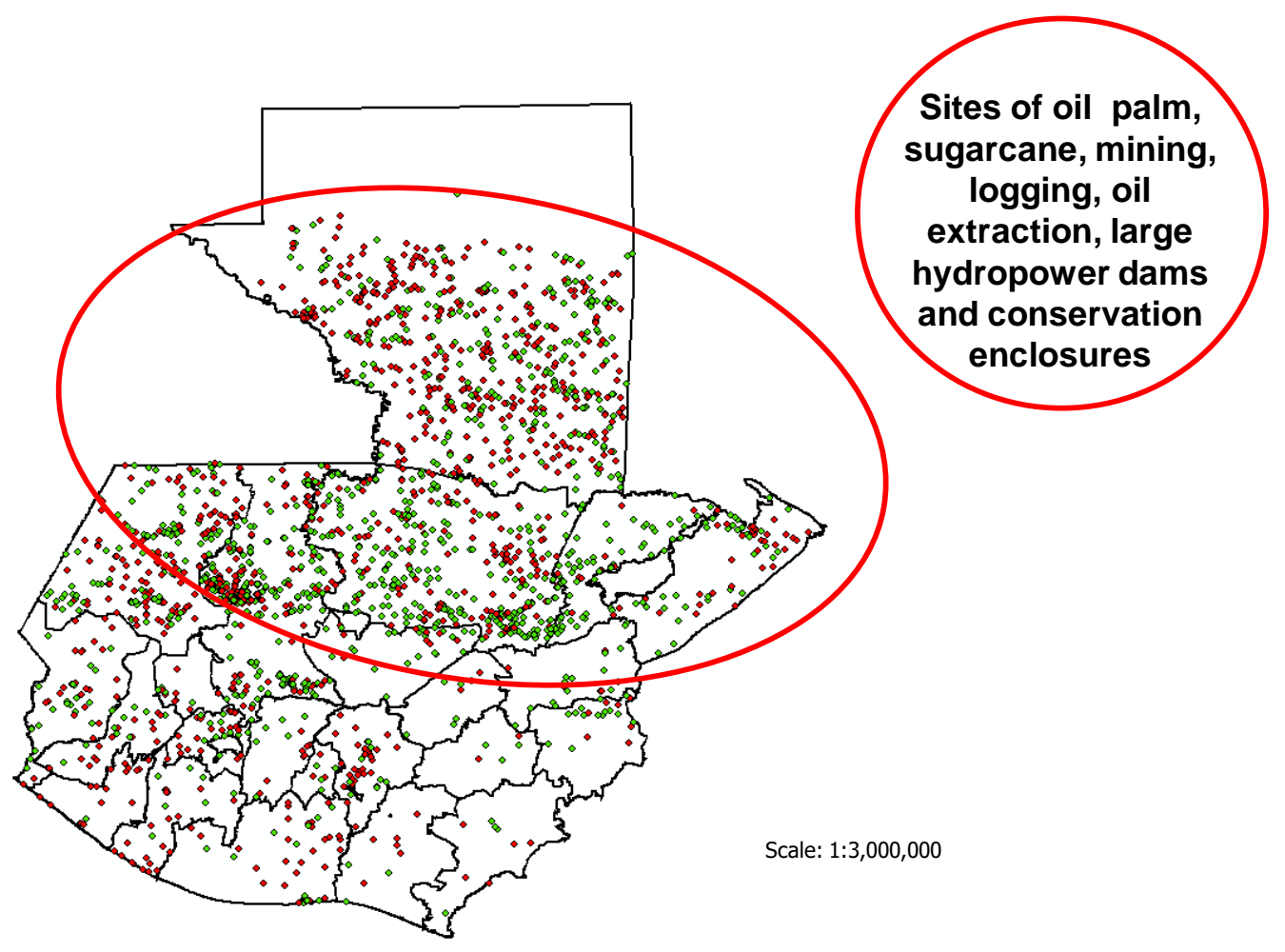

Source: Based on Government of Guatemala (http://portal.saa.gob.gt/ accessed on July 25, 2012).

Negative experiences with FONTIERRAS' Market-Led Agrarian Reform and land titling programmes motivated many $Q^{\prime}$ eqchi' lowlanders to move away from a "freehold land property route" towards securing private property rights over particular land plots, to a "defense of territory route" towards achieving juridical-political status as subjects of collective rights in their territory. Accordingly, Q'eqchi' overt and structured struggles around land are no longer so much about securing land property rights, but about developing and strengthening their own abilities to control and use land as a means of production, and as territory. Structured forms of contention in defense of territory by Q'eqchi' lowlanders include both defensive and offensive strategies. The former are aimed at developing and strengthening their abilities to maintain and control access to land resources. The latter seek to (re)gain access to land, and to improve the terms of incorporation into the agrarian extractivist project.

Regarding the defensive, structured forms of contention, Q'eqchi'ideologues and grassroots organizations alike, suggest that forcing the state to formally recognize communities as subjects of collective rights is a relatively simple 'juridical juggling'22. Aware of the fact that law is neither self-interpreting nor self-implementing (Franco 2008) they argue that the state's recognition is of little use if not underpinned by strong grassroots organization and vibrant livelihoods. Hence, defensive strategies to maintain

\footnotetext{
22 In APROBASANK's workshop in Guatemala City, June 262013
} 
and control access to land resources revolve around community self-determination in the ideologico-political and economic realms. There are ongoing initiatives to strengthen community-led systems of governing village politics in general, and the social relations around land, water and other natural resources in particular. One common practice of contention in this regard, is the refusal to give right of way through village lands to trucks, machinery or workers from sugarcane or oil palm agribusinesses. Many a time this is done in retaliation for similar practices carried out by the companies. Another recurrent practice to resist dispossession is that of counterruling freehold land tenure. For example, a communal deed from a Sayaxché village states: 'In the villages where companies are settled, people's freedom is not respected...they privatize all that is indigenous people's patrimony [...] so we agree none of us will engage in any land deals with them' (community deed number 19-2007). Other times, community members are prevented from leasing or lending farmland to those who had sold their land before to a rancher or to an agribusiness without a community-sanctioned reason, or without offering it first to other members. Similar practices include that of not accepting as a new community member anyone known to have voluntarily sold his/her land before, and that of expelling from the village anyone who challenges these rulings.

Notwithstanding, counter-ruling freehold land tenure is rarely effective if the reasons for villagers with individual land titles to engage in land deals are not comprehensively addressed. Thus, there are, in addition, initiatives to strength community livelihoods. Most often, available livelihood options for rural Q'eqchi' lowlanders revolve around farming. Freehold land tenure has contributed to the shift from a communal system of yearly allocation of farmland according to every family's reproductive needs, to one in which the village lands became privately owned and "fixed" in time and space. As many as eight out of ten Q'eqchi' families from the northern lowlands had to abandon an agro-ecologically, culturally, and socially sound ${ }^{23}$ swidden farming system for a more intensive one, suitable to the freehold land tenure regime. Agricultural intensification has usually been akin to increasing dependence on petro-chemical inputs. Evidence from socio-ecological metabolism analysis of Q'eqchi' peasant households (Mingorría et al. 2014) and from sustained low external input agricultural practices (AVSF and APROBASANK 2011) show, however, that the means to higher yields in the karstic soils of the northern lowlands has little to do with a new Green Revolution miracle. Successful agricultural intensification has more to do with the ability of the family to divert higher amounts of labor towards a low external input-dependent intensification strategy. Becoming aware of this, and lacking support from decimated government extension agencies, groups of Q'eqchi` lowlanders are being supported by their grassroots organizations, and a few committed (inter)national NGOs, to develop 'Campesino a Campesino, 24 agroecological knowledge exchanges, on the one hand, and

\footnotetext{
${ }^{23}$ See Schwartz (1990), Grandia (2012) and Grünberg et al. (2012) among others.

${ }^{24}$ See Holt-Giménez (2006) for a compelling historization of this movement in Central America.
} 
'Peasant Markets' ${ }^{25}$ in search of more favorable terms of exchange and increased control over local food distribution and sales, on the other hand. Whilst both, 'Campesino a Campesino' exchanges and 'Peasant Markets' are not necessarily "new", they have been re-signified within this cycle of contention as means of struggle against the expansion of oil palm and sugarcane agribusinesses. This represents one of the multiple ways in which the food sovereignty frame informs, and contributes to, defense of territory (and vice versa).

The offensive strategies within more structured forms of contention in defense of territory include struggles for repossession, for access to land resources, and for better terms of incorporation to the agrarian extractivist project. These are often confrontational struggles involving a wide range of Q'eqchi' rural working classes. Two cases of struggles for repossession are worth describing here because of their particular character of "access without control". The first one is that of a community from Fray municipality, which had its land officially titled in 1981, long before the FONTIERRAS Market-Led Agrarian Reform. Around 20 hectares of community land were seized by a large cattle rancher in the late 1990s, and since then community representatives have been complaining to FONTIERRAS about it. FONTIERRAS officials reassured them there was no need for concern because the land was titled in their name. In 2008 the cattle rancher became an out-grower for an oil palm company and planted the contested 20 hectares with oil palm. Discouraged by government inaction, the community decided to occupy the plantation, chop-off the branches from the oil palms, and plant maize among them. In an interview in October 2009, company representatives claimed that 'the problem is between the community and the out-grower; we have nothing to do with it'. The conflict was not yet resolved by May 2014. The second case involves another oil palm company and a Q'eqchi' village from Raxruhá municipality. In June 2012, the community council filed a petition to FONTIERRAS because 2.5 hectares of community land were seized by the company to establish an oil palm nursery. A freshwater creek supplying the village flows through the contested land, and villagers maintain the company polluted it with agrochemicals. In November 2012, the villagers decided to put pressure on FONTIERRAS and blocked the nearby national road. They allowed drivers to bypass the blockage only after they had carried two baby oil palms from the nursery and into the middle of the road. The company was forced to withdraw from the 2.5 hectares of land, but up until May 2014, villagers were still being harassed by the companies' private security when fetching water from the creek.

Notwithstanding other practices ${ }^{26}$, land occupations remain the most common way of gaining access to land resources beyond FONTIERRAS' market mechanism. The most striking example in Guatemala's recent history is the 2010 occupation of sugarcane plantations by around 800 landless Q'eqchi' families in the Polochic Valley. It was here

\footnotetext{
${ }^{25}$ Ongoing successful examples include the weekly peasant markets in Chisec and Raxruhá where only direct producers can sell their produce

${ }^{26}$ Such as being granted access to communal land resources by the community council, or claiming land legally as an in-kind payment for unobserved wages and labor liabilities as former estate colonos
} 
that, from 2005 onwards, an agribusiness purchased 5,400 hectares of land from traditional estates to move its sugar mill from the southern Pacific region to the Polochic. As mentioned, the Polochic Valley was basically inhabited by Q'eqchi' families living under long-term colonato relations. Since 2002, most of these families were already negotiating with their patron the purchase of the estate's land through FONTIERRAS. Negotiations dragged on due to FONTIERRAS' bureaucratic procedures, and suddenly came to an end when the sugar mill arrived in the Polochic Valley. The offer of a higher price and immediate payment by the sugarcane agribusiness quickly convinced traditional estate owners to call an end to negotiations with their colonos. In retaliation, hundreds of landless Q'eqchi' families from the valley and the surrounding hilly areas occupied fourteen estates in November 2010. Five months later, 1,500 soldiers and policemen, together with the company's private security staff, evicted all families from the estates.

Crops and houses were burned down and one Q'eqchi' squatter was killed by the police. Two more would be assassinated later on by hitmen. In June 2011 the Inter-American Human Rights Commission called on the Guatemalan state to secure the life and food security of the evicted families. (Franco et al. 2012,9)

In October 2013, the President of Guatemala announced the allocation of a 3.5 hectares plot to every family. As of May 2014, less than $10 \%$ of the evicted families have been granted such land, and two of the estates were occupied once again. Nevertheless, the sugarcane mill was in full production.

The third and last category of the offensive type of structured forms in defense of territory entails struggles for better terms of incorporation into the agrarian extractivist project, either as plantation workers, or as out-growers. On the one hand, and particularly in Sayaxché, where most farmland is under oil palm cultivation, Q'eqchi' plantation workers have been struggling for increased wages and de-flexibilized labor arrangements and conditions. Following a major strike during 2012, a negotiating table was promoted by government representatives. Whenever negotiations became stuck, or the companies hired workers from other regions to put pressure on them, local workers would ban any truck with fresh oil palm fruit from accessing the mills. Some consider it to be a great success that every worker is now paid the official minimum wage, and carried to work in a bus instead of in cattle trucks (interview with the workers' representative in the government negotiating table on November 2013). For others, mainly casual landed laborers, but also landless ones, these are not achievements, but just the minimal observance of basic labor rights (group meeting with village representatives from Sayaxché, November 2013). On the other hand, half of the 300 small-scale oil palm outgrowers in Guatemala claimed, in a letter sent on December 2013 to their contractor, that 'the company promised oil palm cultivation was the way out of poverty. However, after four years of meager financial and technical support, together with increasingly unfavorable conditions of exchange, oil palm is rather leading us to bankruptcy and landlessness'. 
All these forms, strategies and practices informing the repertoire of contention in defense of territory are relatively well-known among contending actors. Yet a distinctive feature from previous cycles of contention lies in the way this repertoire is activated nowadays. In fact, these practices of struggle are increasingly conceived not so much as an end, but as a means for strategic litigation processes. Strategic litigation involves grounded practices of resistance exerting pressure "from below", together with politico-juridical advocacy "from above", and support from research and social communication "from the sides". This is why many Q'eqchi' grassroots organizations and village representatives are working on alliance building with different actors within and beyond the local/territorial scales.

\section{Scaling up contention: the politics of alliance-building in defense of territory}

Becoming aware of the structural nature of their grievances, many Q'eqchi' grassroots organizations, and entire communities, are willing to get involved in strategic litigation processes as a means to amplify their struggle in defense of territory. This requires forging tactical and strategic alliances. Q'eqchi' lowlanders have found not many, but definitely diverse, allies. These include (inter)national militant rural social movement organizations, (inter)national development and human rights NGOs, alternative media networks, engaged researchers, some representatives of the Catholic Church, and even some progressive state actors. Among the latter, the "two doors policy" group of government officials stands out. Led by the Rural Development Bureau Secretariat, this group advocates for differentiated policy responses to peasant farming, and agrarian extractivism. They believe there are 'intersections and possible complementarities among these agricultural development models' (Minister of Food, Livestock and Agriculture ${ }^{27}$ ). Advocates of this viewpoint current are critical of both radical rural social movements and ultra-conservative oligarchs - a convenient positioning for those promoting an 'extractivism committed to the rule of law and the green economy principles, with corporate social and environmental responsibility' (Director of Strategic Policy, Ministry of Natural Resources and Environment ${ }^{28}$ ).

An ally more committed to strategic litigation, though less influential within the state, is the mayor of Raxruhá municipality. He was sued in the Constitutional Court by the oligarchic Guatemalan Agricultural Chamber (Cámara del Agro) after trying to tax oil palm companies in order to 'recover part of the huge expenses we have to pay to restore what they destroy and pollute' (interview with Raxruhá mayor, August 2013). This move by the Agricultural Chamber, and the negative Court verdict in May 2014, radicalized the mayor and the other fifty-six auxiliary community mayors, who now demand that oil palm companies leave (assembly of Raxruhá village authorities, May 2014).

\footnotetext{
${ }^{27}$ In "Conference on Agrarian and Rural Dynamics in $21^{\text {st }}$ Century Guatemala", October 112011 , Rafael Landivar University, Guatemala

${ }^{28}$ In government's "I National Congress on Racism and Discrimination”, August 7-9 2013, Guatemala
} 
Notwithstanding, Q'eqchi' lowlanders are linking more systematically with national militant peasant, indigenous, rural women and youth movements' organizations ${ }^{29}$, and their allies. This is not an easy endeavor. Changing class configurations intersect with age, gender and kinship attributes, resulting in an increasingly complex range of positionings within and across Q'eqchi' communities. This is not always read properly by militant peasant organizations, which can approach Q'eqchi' villages as a tabula rasa of peasants struggling for autonomy (van der Ploeg 2010). This is part of the story, but definitely not the whole story. Militant cadres complain about 'how hard it is to organize people to struggle for land reform' (interview with a community organizer from a major militant peasant organization, October 2009) while village representatives claim sometimes that national organizations do not pay enough attention to local politics and the pace of struggle (group meeting with authorities from different villages, November 2013). Some grassroots organizations complain that national militant peasant organizations are still very much influenced by Socialist imaginaries, and do not take on board their particular claims as indigenous peoples (interview with a representative from an influential grassroots organization, October 2013). Indeed, Q'eqchi' lowlanders' demands in defense of territory are too "indigenist" for some peasant organizations, while their food sovereignty vision is too "peasantist" for some PanMayan indigenous organizations.

Nonetheless, Q'eqchi' grassroots groups are engaging more and more actively with, and many times even becoming part of, militant rural social movements (often linked to transnational activist networks) to scale-up their struggles in defense of territory. Conversely, Q'eqchi' lowlanders' place-based practices of resistance allow for the relocalization of national militant rural social movements. These where somehow detached from territorial practices of resistance from the mid-1990s to the mid-2000s during their commitment to energy-consuming contention in the national and international arenas ${ }^{30}$. Place-based practices of resistance by the Q'eqchi' (and others) in defense of territory are, indeed, reshaping from below the frames and repertoires of contention of national rural social movements. The "land-to-the-tiller" and "food sovereignty" frames are resignified within defense of territory. One example of this is "The Popular, Peasant, Women and Indigenous March" (La Marcha Indígena, Campesina, Popular y de Mujeres). Originally planned by evicted families in the Polochic Valley and a major national militant peasant organization as a nine-day march from Cobán to Guatemala City, it became a major political event. Some 15,000 people walked into the capital city on March 27, 2012 and handed petitions to the President and the Congress. The government agreed upon four points related to agrarian conflict resolution and stricter controls over private armed groups. President Pérez Molina stated that other demands like 'cancelling the debt of hundreds of peasant groups with FONTIERRAS, a moratorium on development projects led by private investors, and the

\footnotetext{
${ }^{29}$ With few exceptions from the environmental justice side, alliances with environmental organizations have been difficult and rare, not to mention those with big international conservation NGOs. On the latter see Ybarra (2011) and Grandia (2012).

${ }^{30}$ I.e., struggling against the makings of the neoliberal food system at the World Trade Organization and around the negotiations of free trade agreements
} 
withdrawal of new military detachments were signed with many reservations' (Prensa Libre March 28, 2012). As for Congress, a deed was signed where representatives from most parties agreed on the fast-track approval of Initiative 4084 on the "Comprehensive Rural Development System Law". Mostly unfulfilled so far, "The March" petitions illustrate a coordinated response to the strategies deployed by multiple actors working on the making of governable spaces to accommodate agrarian extractivism.

\section{Repertoire of contention in the promotion of the agrarian extractivist project}

Frames and repertoires of contention are critical arenas of struggle in themselves, which serve 'just as easily for social control as for insurgency' (Tarrow 1998, 202). In their making of governable spaces to advance agrarian extractivism, while at the same time countering struggles in defense of territory, corporate, state and social actors employ a repertoire of contention based in three mutually reinforcing strategies. One could be described as the Trojan horse ${ }^{31}$ strategy. Its aim is to divide and rule through enticement in the local/territorial scales, and its fundamental form of contention is of a discursive and symbolic nature. The second one is the pretty up strategy. This is intended to make the agribusinesses' accumulation project seem to be one of socially responsible solutions to pressing ecological problems, across geographical scales. The pretty up strategy also relies on enticement, and its fundamental forms of contention are of a discursive and private regulatory nature. The third strategy is that of ruling by fiat. It involves ensuring an openly biased interpretation and implementation of statutory regulation towards particular (corporate) interests, be the only one that complies with the "rule of law" in everybody's interests. This strategy has the double intention of securing what was accomplished through enticement and achieving through legal coercion and/or the use of physical force, what enticement could not. Its fundamental forms of contention are of a statutory regulatory and repressive nature. The character of these three strategies is schematically depicted in Figure 6 below.

\footnotetext{
${ }^{31}$ I am thankful to SiuSue Mark for suggesting this formulation.
} 
Figure 6: Strategies, forms and practices of the repertoire of contention in the promotion of the agrarian extractivist project

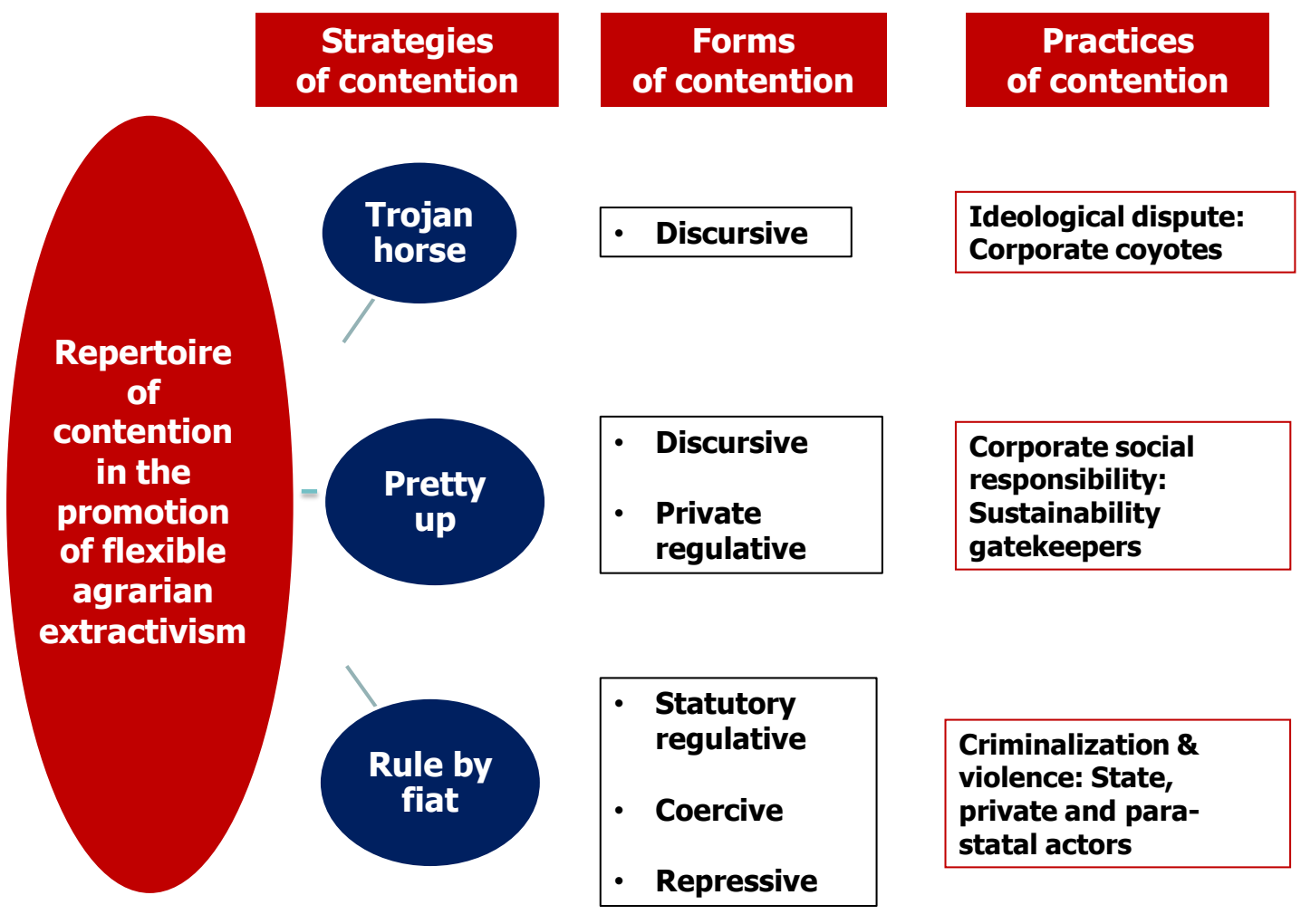

Source: Author's elaboration

Actors pushing for agrarian extractivism are aware of the fact that consent and legitimation in the local/territorial scales today, are at least as important as in national and international ones. They are also clear that 'beliefs, ideological controls and discursive practices, as well as negotiated systems of meaning, shape all forms of access [to resources]' (Ribot and Peluso 2003, 168). That is why oil palm and sugarcane agribusinesses use the Trojan horse strategy to influence the ideological dispute around the symbolic power (Bourdieu 1989) underpinning dominant knowledge, beliefs and practices in Q'eqchi' villages and communities. The agribusinesses' Trojan horse is full of what people call "corporate coyotes". These are locally recognized and charismatic subjects $^{32}$, who are either hired occasionally, or directly employed by the companies. As argued by a group of dispossessed families from Sayaxché:

They came to cheat us. "You better sell your land before it is flooded by the Puebla to Panama Plan hydroelectric mega-dams", they said. "The companies will provide employment and welfare that the state cannot", they also told us. And they were not people from faraway places, not even company lawyers or engineers. They were our brothers from neighboring villages! (Group meeting in March 2010).

Corporate coyotes can therefore pervade communal institutions to counter dominant knowledge and imaginaries in the community, like those informing social relations

32 They include preachers, teachers, doctors, NGO representatives, community leaders, local radio station announcers, traditional landlords/patrons, ranchers, village mayors, corn traders, civil servants, etc. 
around land, water and other natural resources. They elaborate on class, gender, generational, or any other power cleavage available, to erode and reframe the community consensus. The coyotes understand that socially differentiated subsistence minimums lead to multiple positionings within and across communities. Broadly speaking, it is mainly Q'eqchi' young, landless men who are often more enticed by the "fast monies" offered by sugarcane and oil palm agribusinesses. There are also youngsters who would rather farm or look for another type of wage work, and those who changed their mind after realizing that 'money goes as fast as it comes and you have to work yourself into the ground in the plantation for it; it is just not a good deal' (group interview with young Q'eqchi' men from Sayaxché, June 2013). Conversely, Q'eqchi' women across age groups, peasant and working classes are often the first to act against their partners' or fathers' will to engage in deals with the agribusinesses. As discussed before, women usually act individually and covertly, though they can also join forces to push through gendered hierarchies in community government bodies, and challenge corporate coyotes' narratives.

However, building a favorable consensus is just a part of the coyotes' job. There is a need to 'mobilize' the new consensus (Tarrow 1998, 175) within and across community groups, so that social opposition is pre-empted, and people willingly ${ }^{33}$ engage in land, labor or out-growing deals with the agribusinesses. Furthermore, for this consensus to become fully hegemonic at the local/territorial scales it is necessary to go beyond peasant and rural working classes to include other relevant actors, such as local government officials, traditional landed upper classes, grassroots organizations and even different churches. For example, together with the small-scale oil palm outgrowers mentioned before, there are medium and large sugarcane and oil palm outgrowers who are anything but happy with their long-term contract-farming arrangements (interview with a large oil palm out-grower in Fray, December 2013). Some feel the agribusinesses are not supportive enough when problems arise, like the outgrower who was abandoned by the oil palm company in his 20 hectares land conflict with a "bordering" community in Fray municipality. Or, many owners of traditional large estates and ranches who refused to (or could not) join the flex crops bandwagon, feel socially displaced and negatively impacted by expanding plantations. Medium and large cattle ranchers complain their cattle get sick, often after drinking the water running through or by plantations under intense agrochemical inputs, or become stressed by the plague of flies around the mills (interviews with ranchers from the northern lowlands during 2013/2014).

The Trojan horse strategy is informed by, and an expression of, the pretty up strategy. The sugarcane, and especially the oil palm industries, are reframing their social image from simply another accumulation project to the 'answer' to food and energy insecurity, climate change, rural poverty and un-governability, just as it was defended by industry representatives from Guatemala, Honduras, Colombia and Ecuador during the First

${ }^{33}$ Indeed, the ideological dispute played out by corporate coyotes shapes all kind of decision-making processes, including Free Prior and Informed Consent (FPIC) by "the community". 
Latin American Congress of Oil Palm Growers (October 17-18 2013, Antigua Guatemala). In fact, the oil palm industry wants to project itself as a "sustainable" and "responsible" type of answer to these problems. In prettying up agrarian extractivism as a socially responsible and ecologically sustainable project, what I call "sustainability gatekeepers" are of outstanding relevance. No matter whether intentionally or not they play a major role in resignifying oil palm from a hazard, to the best option for rural working classes and the environment. Sustainability gatekeepers are championed by big development and conservation (inter)national NGOs, but can also include universities and consultancy firms, which are part and parcel of corporate social responsibility (CSR) initiatives such as the Roundtable on Sustainable Palm Oil (RSPO), BONSUCRO, or the Roundtable on Sustainable Biomaterials (RSB). First, they bargain over the set of social and ecological standards particular to each initiative with the corporate actors involved. And then these sustainability gatekeepers are hired by the very same companies to evaluate whether they comply or not with those standards in order to be granted the "sustainability seal". Both corporate coyotes and sustainability gatekeepers 'coincide with the greater political power and have a hegemonic advantage [hence] a preeminent position in crafting emergent dominant traditions' (Sivaramakrishnan 2005, 350). Indeed, via the "Guatemalan Sugar Producers Association" (ASAZGUA) and the "Oil Palm Growers Guild" (GREPALMA) these agribusinesses are well represented on the powerful "Guatemalan Agricultural Chamber" and from there, on the almighty "Coordinating Committee of Agricultural, Commercial, Industrial, and Financial Associations" (CACIF). Whilst there are various others, CACIF is the main ideologue prettying up agrarian extractivism as the socially responsible and environmentally sustainable "national development" project.

Yet, when enticement and CSR strategies fall short, there is always the possibility to rule by fiat. As argued by $\mathrm{Li}$, 'more authoritarian forms of government are often reserved for sections of a population deemed especially deficient and unable to exercise the responsibility of freedom' $(2005,387)$. The owners of the Polochic sugarcane mill, for instance, called on the state to secure the rule of law when violently evicting hundreds of Q'eqchi' families: 'We bring employment and wealth; how are they going to progress with those little maize plants [maicitos]? Who else would be willing to invest US\$ 50 million in this petty valley [vallecito de pipiripau]? Rule of law to protect investors is what is needed here' (Guatevisión May 29, 2011). And rule of law was also what the CACIF called for when suing the mayor of Raxruha in court. However, even though the Constitution acknowledges constitutional hierarchy to international human rights treaties, such as the ILO convention number 169, or the International Covenant on Economic, Social and Cultural Rights, the Constitutional Court does not recognize the outcomes of sixty-one "community consultations held in good faith" between May 2005 and March $2012^{34}$. Ruling by fiat also meant the fast-track approval by the Congress of eight new laws on investment protection and labor flexibility, as promoted by the CACIF in February 2013, while freezing the legal initiative on rural development

\footnotetext{
${ }^{34}$ In all of them, communitarians unanimously rejected different accumulation and development projects ongoing or planned in what they consider their territories.
} 
agreed with "The March". Furthermore, the government is using the 1965 counterinsurgent "Decree 7 on Preventive States of Emergency" to deploy the military in villages where there are land control grab-related conflicts. National attorneys, for their part, deal with disruptive collective action through the Anti-terrorist Bill, and treat land occupations, for instance, as penal offenses of "aggravated usurpation of property". This is leading to dozens of peasant leaders and organizers to be put in jail (interview with a member of the Maya Lawyers Association, Guatemala City, June 2013). This particular interpretation and enforcement of the law speaks for itself regarding whose interests prevail within core institutions of the Guatemalan state.

In addition to state violence, private and parastatal violence is also part of the game. Public tracks are closed by the gates built by sugarcane and oil palm agribusinesses. It is common for the plots belonging to peasants and even to medium-scale ranchers, who refuse to sell or grow oil palm on their land, to end up being enclosed by plantations. Men refusing to sell their land are threatened by the companies' private security staff who use ultimatums such as: 'either you sell at the price we offer, or we will have to bargain with the widow instead' (group meeting in a South Petén village, March 2008). Threats are sometimes carried out, and many have been assassinated or disappeared after refusing to sell their land, or when mobilizing in defense of territory ${ }^{35}$. Whatsmore, if resistance is one side of the survival coin, and compliance is the other, joining criminal gangs, private security forces or becoming a narco hit man are the survival coin's edge of growing despair in the northern lowlands. Scott argued how 'certain combinations of atomisation, terror, repression, and pressing material needs can, indeed, achieve the ultimate dream of domination: to have the dominated exploit each other' $(1986,30)$. Or attack each other. This is the case when groups of generally poor, landless Q'eqchi’ men are hired to assault and/or evict their fellow resisters.

\section{Conclusion}

The current cycle of contention around the agrarian extractivist project in the Guatemalan countryside resembles previous cycles in many ways. For instance, the state persists as both a relevant means for, and an arena of, contestation. And many of the strategies, forms, and practices of contention in defense of territory, and in the promotion of the agrarian extractivist project, have been adapted from previous cycles of contention.

Nonetheless, there are important ruptures with the past too, many of which have to do with the discussed dynamics around the labor regime fix, and the land good governance fix at play. Subsistence minimums are pushed to unprecedented thresholds. There are also new actors such as the financialized flex crop agribusinesses, small-scale oil palm outgrowers, new fragmented classes of rural labor, global land (good) governance institutions and NGOs, multi-stakeholder CSR certification schemes, radicalized

\footnotetext{
${ }^{35}$ It is difficult to give an exact figure because many resisters are attacked in moments and places other than those of direct confrontation. The Social Pastoral of Petén estimated in 'dozens' the number of resisters killed in Petén only between 2004 and 2009 (workshop in Petén, November 2009).
} 
grassroots organizations, and so on, with a sharpened accumulation and governmental project, on one side, and with historically refined practices of resistance, on the other. There are, in short, analytical and political challenges ahead, in and around the emergent agrarian extractivist project.

Framing resistance to agrarian extractivism as defense of territory offers the possibility to bridge "the best of both worlds" informing collective identities in the Guatemalan countryside, that is, community-accountable forms of governing land resources, as indigenous peoples, and low external input farming practices, as peasants. It also allows for grounding the vision of food sovereignty, while making of it both a fundamental means of struggle against the agrarian extractivist project and a vision informing a transformative life project. However, the defense of territory master frame also brings new challenges with regards to Borras' and Franco's differentiated political reactions "from below" to landgrabbing. First, a representational challenge: the unified bearer of collective rights enshrined within defense of territory, that is, the (indigenous-peasant) "community", is subject to major social differentiation dynamics. Second, a targeting challenge: strengthening farming livelihoods and community command over land relations may provide the necessary means and meanings for resistance. But whether, and how, to engage with the state regulatory powers remain so far unresolved and central questions if such self-determined practices aim to have a future within a transformative project. And lastly, an alliance-building challenge: in scaling up resistance towards strategic litigation processes, there remains the hurdle of the knowledge dialogue between, across and within village authorities, grassroots collectivities, national militant peasant, indigenous and women movements' organizations, and other allies in the academia, the media, the (I)NGO community, and the state.

Efforts to assess the political dynamics of contemporary agrarian change in socioagroecological settings like the ones discussed here will benefit, thus, from engaging with the politics of the making of governable spaces to accommodate the agrarian extractivist project. In doing so, it is critical to examine the changing practices of, and relations between, across and within multiple corporate, state and social actors who are pushing for, resisting, complying with, or operating at the most violent margins of the agrarian extractivist project. Following this multiple politics perspective, then, it is worth stressing again that trajectories of agrarian change are not a story foretold, but the product of multiple and dynamic politics.

\section{Acknowledgements}

The author is most grateful to the Editors of this collection and to the two anonymous reviewers for their meaningful comments. He is also very thankful to Jun Borras, Mindi Schneider, Max Spoor, SiuSue Mark, Ben Mckay, Zoe Brent, María Banos Smith, Tsegaye Moreda Shegro, Daniela Andrade, and Natalia Mamonova for their very helpful comments on earlier versions and/or copy-editing support. Any remaining errors are his own. 


\section{Short note on the author}

Alberto Alonso-Fradejas is a $\mathrm{PhD}$ Candidate at the International Institute of Social Studies (ISS) in The Netherlands, Research Associate of the Transnational Institute (TNI), and Fellow of the Guatemalan Institute of Agrarian and Rural Studies (IDEAR). Email: fradejas@iss.nl

\section{References}

Acosta, 2013, Extractivism and neoextractivism: two sides of the same curse. In M. Lang and D. Mokrani eds. Beyond Development: Alternative visions from Latin America. Quito/Amsterdam: Transnational Institute / Rosa Luxemburg Foundation.

Akram-Lodhi, A.H., and C. Kay, 2009, 'The agrarian question: peasants and rural change' in A.H. Akram-Lodhi, A.H. and C. Kay (eds.) Peasants and globalization: political economy, rural transformation and the agrarian question, pp. 3-34. London: Routledge.

Altieri, M.A. \& Toledo, V.M. 2011 'The agroecological revolution in Latin America: rescuing nature, ensuring food sovereignty and empowering peasants', Journal of Peasant Studies 38(3): 587612

Alonso-Fradejas, A., 2012, 'Land Control-Grabbing in Guatemala: The Political Economy of Contemporary Agrarian Change', Canadian Journal of Development Studies 33(4): 509-528.

Alonso-Fradejas, A., J.L. Caal Hub, and T. Miranda Chinchilla, 2011, Plantaciones Agroindustriales, Dominación y Despojo Indígena-Campesino en la Guatemala del Siglo XXI. Guatemala: IDEAR and Magna Terra Editores.

AVSF and APROBASANK, 2011, Agriculturas Campesinas En Zona De Frontera Agrícola, Estudio De Casos. Chisec, Guatemala: Unpublished.

Bebbington, A., 2007, Minería, Movimientos Sociales y Respuestas Campesinas: Una Ecología Política De Transformaciones Territoriales. Vol. 2. Lima: Instituto de Estudios Peruanos

Bernstein, H. 1998. Labour regimes and social change under colonialism. In: Ben Crow, Mary Thorpe et al., eds. Survival and change in the third world. Cambdridge: Polity Press, pp. 30-49.

Bernstein, H., 2004, “"Changing Before Our Very Eyes": Agrarian Questions and the Politics of Land in Capitalism Today'. In Redistributive Land Reform Today, ed. T.J. Byres, Journal of Agrarian Change 4(1-2): 190-225.

Bernstein, H., 2006, 'From Transition to Globalization: Agrarian Questions of Capital and Labour', International Conference on Land, Poverty, Social Justice and Development, 9-14 January 2006, Institute of Social Studies pp.1-22.

Bordieu, P., 1989, 'Social Space and Symbolic Power', Sociological Theory 7(1): 14-25.

Borras, S.M., J.C. Franco, R. Isakson., L. Levidow, and P. Vervest, 2014, 'Towards understanding the politics of flex crops and commodities: Implications for research and policy advocacy', Think Piece Series on Flex Crops \& Commodities No.1, Amsterdam, Transnational Institute (TNI)

Borras, S.M. \& J.C. Franco, 2013, 'Global Land Grabbing and Political Reactions 'From Below', Third World Quarterly, 34:9, 1723-1747

Borras, S.M., J.C. Franco, S. Gómez, C. Kay and M. Spoor, 2012, 'Land Grabbing in Latin America and the Caribbean', Journal of Peasant Studies 39(3-4): 845-872. 
Byres, T.J., 1991, 'The Agrarian Question and Differing Forms of Capitalist Transition: An Essay with Reference to Asia'. In Rural Transformation in Asia, eds. J. Breman and S. Mundle, 3-76. Delhi: Oxford University Press.

Byres, T.J., 1996, Capitalism From Above and Capitalism From Below. An Essay in Comparative Political Economy. London: Macmillan.

Castellanos Cambranes, J.C., 1996 [1985], Café y campesinos. Los orígenes de la economía de plantación moderna en Guatemala, 1853-1897. Madrid: Catriel.

Comisión para el Esclarecimiento Histórico, 1999, 'Conclusiones Y Recomendaciones Del Infrome De La Comisión Para El Esclarecimiento Histórico', Guatemala Memoria del Silencio Tz'inil Na'tab'al. Guatemala: United Nations.

Declaration of Nyéléni, 27 February 2007, accessed on September 22, 2014 http://www.nyeleni.org/IMG/pdf/DeclNyeleni-en.pdf

Du Toit, A., 2004, 'Social Exclusion Discourse and Chronic Poverty: A South African Case Study', Development and Change 35(5): 987-1010.

Dürr, J., 2011, 'Diez mitos y realidades sobre las cadenas agroalimentarias en Guatemala, y una cuenta nacional de base agraria. Documento de Trabajo para Discusión'. Guatemala: GIZ/IDEAR.

Edelman, M., and A. León, 2013, 'Cycles of Land Grabbing in Central America: An Argument for History and a Case Study in the Bajo Aguán, Honduras', Third World Quarterly 34(9): 1697-1722.

Engels, F., 1951[1894], The peasant question in France and Germany. In: K. Marx and F. Engels, eds. Selected works, Vol. 2. Moscow: Foreign Languages Publishing House, pp. 381-99

Fairbairn, M., 2014, 'Like Gold with Yield': Evolving Intersections between Farmland and Finance', Journal of Peasant Studies 41(5): 777-795.

Figueroa Ibarra, C., 1980, El Proletariado Rural En El Agro Guatemalteco. Guatemala: Editorial Universitaria USAC.

Fine, B., 2012, 'La Financiarisation En Perspective', Actuel Marx 51: 73-85.

Foster, J.B., 2000, Marx's Ecology: Materialism and Nature. New York: Monthly Review Press.

Franco, J.C., 2008, 'Making Land Rights Accessible: Social Movement Innovation and PoliticalLegal Strategies in the Philippines'. Journal of Development Studies, 44 (7): 991-1022

Franco, J.C., S.M. Borras, A. Alonso-Fradejas, N. Buxton, R. Herre, S. Kay, and T. Feodoroff, 2012, 'The Global Land Grab: A Primer', Amsterdam: Transnational Institute.

Friedmann, H. and P. McMichael, 1989, 'Agriculture and the State System: The Rise and Decline of National Agricultures, 1870 to the Present', Sociologia Ruralis 29(2): 93-117.

Goodman, D., B. Sorj, and J. Wilkinson, 1987, From Farming to Biotechnology. A theory of Agroindustrial Development. Oxford and New York: Basil Blackwell

Grandia, L., 2012, Enclosed: Conservation, Cattle, and Commerce among the Q'Eqchi' Maya Lowlanders. Seattle: University of Washington Press.

Grandin, G., 2004, The Last Colonial Massacre: Latin America in the Cold War. Chicago: University of Chicago Press.

Gregory, D., R. Johnston, G. Pratt, M. Watts and S. Whatmore, 2009, The Dictionary of Human Geography. U.K: Wiley-Blackwell. 
Gudynas, E., 2009, Diez tesis urgentes sobre el nuevo extractivismo. Contextos y demandas bajo el progresismo sudamericano actual. In: Centro Andino de Acción Popular (CAAP)/Centro Latinoamericano de Ecología Social (CLAES) (ed.): Extractivismo, Política y Sociedad. Quito: CAAP/ CLAES, 187-225.

Handy, J., 1984, Gift of the devil: A history of Guatemala (Vol. 2). Toronto: Between the Lines.

Harvey, D., 2003, The New Imperialism. New York: Oxford University Press.

Hernández, O.J., 2012, 'Desplazar Para no Ser Desplazados' Plaza Pública, 30 September.

Holt-Giménez, E., 2008, Territorial Restructuring and the Grounding of Agrarian Reform: Indigenous Communities, Gold Mining and the World Bank' TNI Land Policy Series 2, Amsterdam: Transnational Institute.

Holt-Giménez, E., 2006, Campesino a Campesino: Voices from Latin America's Farmer to Farmer Movement for Sustainable Agriculture. Oakland: Food First Books.

Hunsberger, C., \& Alonso-Fradejas, A., 2015, 'The discursive flexibility of 'flex crops': comparing oil palm and jatropha' (forthcoming)

Hurtado, L., 2008, Dinámicas Agrarias Y Reproducción Campesina En La Globalización. El Caso De La Alta Verapaz. Guatemala: F\&G Editores.

Hurtado, L. and G. Sánchez, 2011, '¿Qué Tipo de Empleo Ofrecen las Empresas Palmeras en el Municipio de Sayaxché, Petén?', pp. 1-60. Guatemala: Action Aid.

IAASTD International Assessment of Agricultural Knowledge, Science and Technology for Development, 2009, 'Agriculture at a crossroads. Global Report', Washington: UNDP, FAO, UNEP, UNESCO, World Bank, WHO, Global Environment Facility.

Isakson, R., 2014, 'Food and finance: the financial transformation of agro-food supply chains', Journal of Peasant Studies, 41(5): 754-782

Jessop, B., 2010, 'Cultural Political Economy and Critical Policy Studies', Critical Policy Studies 3(3-4): 336-356.

Jessop, B., 2007, State Power. Cambridge: Polity Press.

Kautsky, K., 1988 [1899], The Agrarian Question. (2 Vols.) London: Zwan.

Lander, E., 2011, 'The Green Economy: the Wolf in Sheep's clothing', TNI Working Paper, Amsterdam: Transnational Institute.

Leff, E., 2006, La Ecología Política en América Latina. Un campo en construcción. In: Alimonda, H. (ed.): Los tormentos de la materia. Aportes para una ecología política latinoamericana. Buenos Aires: CLACSO, 21-39.

Lenin, V.I., 1964 [1899], The Development of Capitalism in Russia: The Process of Formation of a Home Market for Large-Scale Industry ( $2^{\text {nd }} e d n$.) Moscow: Progress Publisher.

Li, T.M., 2005, 'Beyond “the State" and Failed Schemes', American Anthropologist 107(3): 383-394.

Li, T.M. 2011. Centering Labor in the Land Grab Debate. Journal of Peasant Studies 38(2): 281-298

Martínez-Alier, J., 2002, El ecologismo de los pobres: conflictos ambientales y lenguajes de valoración, Barcelona: Icaria. 
Martínez Peláez, S., 1976, La Patria Del Criollo: Ensayo De Interpretación De La Realidad Colonial Guatemalteca. San Jose: Editorial Universitaria Centroamericana.

Marx, K., 1974 [1867], Capital: A Critique of Political Economy. Vol. I. London: Lawrence\&Wishart.

McCreery, D., 1994, Rural Guatemala, 1760-1940. Stanford: Stanford University Press.

McMichael, P., 2012, 'The Land Grab and Corporate Food Regime Restructuring', Journal of Peasant Studies 39(3-4): 681-701.

Mingorría, S., Gamboa, G., B., Martín-López, and \& E., Corbera, 2014, 'The oil palm boom: Human wellbeing implications for Q'eqchi' communities in the Polochic valley, Guatemala' Environment, Development and Sustainability 16: 841-871.

Moore, J., 2011, 'Transcending the metabolic rift: a theory of crises in the capitalist world-ecology', Journal of Peasant Studies 38(1): 1-46.

Netting, R.M., 1993, Smallholders, Householders: Farm Families and the Ecology of Intensive, Sustainable Agriculture. California: Stanford University Press.

O'Laughlin, B., 2008, 'Governing capital? Corporate social responsibility and the limits of regulation', Development and Change, 39(6): 945-957.

Ribot, J.C. and N.L. Peluso, 2003, 'A Theory of Access', Rural Sociology 68(2): 153-181.

Sanders, K., and Riordan Seville, L., 2012, 'Mystery kidney disease decimates Central America sugarcane workers', October 16, NBC News, accessed on September 22, 2014

http://investigations.nbcnews.com/_news/2012/10/16/13866856-mystery-kidney-disease-decimatescentral-america-sugarcane-workers

Schwartz, N.B., 1990, Forest Society: A Social History of Petén, Guatemala. Philadelphia: University of Pennsylvania Press.

Scott, J.C., 1976, The Moral Economy of the Peasant: Rebellion and Subsistence in Southeast Asia. New Haven and London: Yale University Press.

Scott, J., 1986, 'Everyday Forms of Peasant Resistance', Journal of Peasant Studies 13(2): 5-35.

Sivaramakrishnan, K., 2005, 'Some Intellectual Genealogies for the Concept of Everyday Resistance', American Anthropologist 107(3): 346-355.

Solano, L., 2009, 'Estudio Del Destino De La Producción De Caña De Azúcar Y Palma Africana Y La Situación De La Producción Y El Mercado De Agrocombustibles En Guatemala', pp. 1-74. Guatemala: Action Aid.

Tarrow, S.G., 2012, Strangers at the Gates: Movements and States in Contentious Politics. New York: Cambridge University Press.

Tarrow, S.G., 1998, Power in Movement: Social Movements and Contentious Politics. (Second edn) Cambridge: Cambridge University Press.

Thompson, E.P., 1971, 'The Moral Economy of the English Crowd in the Eighteenth Century', Past \& Present (50): 76-136.

Van der Ploeg, J.D., 2010, 'The peasantries of the twenty-first century: the commoditisation debate revisited', Journal of Peasant Studies 37(1): 1-30.

Veltmeyer, H., and J. Petras. “The New Extractivism in Latin America”. London: Zed (2014). 
Wagner, R., 2001, Historia del café de Guatemala. Bogotá: Villegas Editores.

White, B., S.M. Borras Jr., R. Hall, I. Scoones and W. Wolford, 2012, 'The New Enclosures: Critical Perspectives on Corporate Land Deals', Journal of Peasant Studies 39(3-4): 619-647.

Ybarra, M., 2011, 'Privatizing the Tzuultaq'a? Private Property and Spiritual Reproduction in PostWar Guatemala', Journal of Peasant Studies 38(4): 793-810. 